\title{
Almost at Home in South Sudan: InTERnATIONAL Christian HumanitaR- IANS AND THE THEOPOLITICS OF RECOGNITION
}

\author{
Amy Kaler \\ JOHN PARKINS \\ ROBIN WILLEY
}

Abstract. In this study, we examine the experience of international Christian humanitarian aid workers and who work in South Sudan. From interviews with thirty people in east Africa and north America, we derive a relationship between Christianity as our participants understand it, and their modalities of encountering "the other" - the people of South Sudan, who may seem different and unfamiliar, yet who must be met as part of religiously motivated life and work. In terrain of South Sudan, we argue that our participants enact a theopolitics of recognition, in which their emotional and practical connections to the people they serve are triangulated through God. This theopolitics operates almost entirely at the individual level, as personal encounters and work are mediated by the assumption of a shared relationship to God. The people of South Sudan are recognized as both familiar and strange, because they share a posited connection to the divine with humanitarians from the global north. We argue that this recognition is different from other ways of encountering the other found in literature ranging from feminist theory to international development. This study thus adds to scholarly knowledge of faith-based organizations and global humanitarianism. We also argue that while the theopolitical modality makes possible certain kinds of ethical action, it may close off other forms of action based in broader political critiques of global relations of power.

Keywords: Theopolitics, South Sudan, Humanitarianism, Christianity, Religion, Travel, Relationally.

Résumé. Dans cette étude, nous examinons l'expérience des travailleurs humanitaires chrétiens étrangers qui travaillent au Soudan du Sud. À partir d'entretiens avec une trentaine de personnes en Afrique de l'Est et en Amérique du Nord, nous formulons une relation entre le christianisme tel que nos participants le 
comprennent et leurs modalités de rencontre avec « l'autre », c'est-à-dire le peuple du Soudan du Sud, qui peut sembler différent et peu familier et qu'ils rencontrent dans le cadre d'une vie et d'un travail motivés par la religion. Au Soudan du Sud, nous soutenons que nos participants adoptent une théopolitique de la reconnaissance, dans laquelle leurs liens émotionnels et pratiques avec les gens qu'ils servent sont triangulés par Dieu. Cette théopolitique fonctionne presque entièrement au niveau individuel, car les rencontres personnelles et le travail sont médiatisés par l'hypothèse d'une relation commune à Dieu. Le peuple du Soudan $\mathrm{du}$ Sud est reconnu à la fois comme familier et étranger, parce qu'il partage un lien posé avec le divin avec les humanitaires du Nord. Nous soutenons que cette reconnaissance est différente des autres façons de rencontrer l'autre que l'on trouve dans la littérature allant de la théorie féministe au développement international. Cette étude s'ajoute ainsi à la connaissance savante des organisations confessionnelles et de l'humanitarisme mondial. Nous soutenons également que si la modalité théopolitique rend possible certains types d'action éthique, elle peut fermer d'autres formes d'action fondées sur des critiques politiques plus larges des relations globales de pouvoir.

Mots clés: Théopolitique, Soudan du Sud, Humanitaire, Christianisme, Religion, Voyages, Relations

\section{INTRODUCTION}

W/ e examine the experience of international humanitarian aid workers who identify as Christian and work in South Sudan. From interviews with thirty people, we derive a relationship between Christianity as our participants understand it, and modalities of encountering "the other" - people who are very different from the self, who are strange and unfamiliar, yet who must be met as part of an ethical life. In the unfamiliar terrain of South Sudan, working and living with people who are very different, we argue that our participants enact a theopolitics of recognition, in which their affective connections to the other are triangulated through God, specifically through recognizing strange and unfamiliar others as fellow children of God. ${ }^{1}$ Our participants' relations to the

1. Researchers have used the term theopolitics in a number of ways. Catholic researcher David Marzak (2016) has used this term to address the collapsing of political and religious realms in liberal democracies. Others have used the term to describe the efforts of Christian political activists, Evangelical and Christian fundamentalist lobbyists in particular (for example see Luban 1996). We use the term theopolitics as means of communicating how theology informs how Christians position themselves and others in the world, and the socio-political boundaries that are inevitably created as a result of this positionality (Anderson 2012). 
Sudanese people they encounter in their work are mediated by the assumption of a shared relationship to God. This recognition is different from other ways of encountering the other that have been documented in literature ranging from feminist theory to international development.

Literature is often critical of humanitarian enterprises, seeing them as a form of neocolonialism or an extension of market-based neoliberalism (e.g. Chouliaraki 2010; Mostafanezhad 2013; l'Anson 2013; Bex and Craps 2016; see also Ticktin 2014 for a broad overview of scholarship on transnational humanitarianism). Critically minded scholars frequently unmask global discourses and institutions to reveal manifestations of racism, cultural superiority and "white savior syndrome" which drive people from the global north to intervene, often badly, in the global south. For example, invoking the language of 'compassion economies' Pedwell identifies an "international aid apparatus where empathic selftransformation can become commodified in ways that fix unequal subjects and objects of empathy" (2012, 165). Similarly, Halvorson (2012, 126), in an article about Lutheran humanitarian aid and the production of bandages, treats Lutheran theologies as

striving to establish an egalitarian "walk" between Lutherans in different world regions - in contrast to broad inequalities of religious and institutional authority seen to characterize Lutheran foreign missions - the notion of "accompaniment" ideologically masks the economic and political dimensions of newer American Lutheran initiatives such as faith-based humanitarianism as well as their continuities with previous foreign mission work.

Such studies explore what Ticktin, in her review of the field, calls

the complexities and aporias of humanitarian principles in practice, teasing out the often contradictory and unstable meanings of key concepts and practices such as neutrality, crisis, engagement, and witnessing (2014, 279).

We believe that this critical enterprise does not exhaust all that can be said about emergency relief and development, whether faith-based or not. Our participants keenly partake in the enterprise of "helping" or "uplifting" the global south, and "white savior syndrome" has an almost literal meaning when applied to people who come bearing food aid in hunger prone regions of South Sudan. These aid workers, however, are far from the stereotype of the well-meaning but blundering northerner who assumes cultural superiority over the people of the south through a 
series of colonial encounters. Recognizing this diversity of experience with north-south encounters, we draw attention to the complex subjectivities and worldviews that are activated in humanitarian enterprises.

One of the few scholars to approach evangelical humanitarianism in South Sudan is Jonathan Agensky, whose 2013 article calls for scholars to attend to the "granularities" of evangelical endeavours in the global south, rather than returning repeatedly to narratives of cultural imperialism and repurposed missionary impulses. Agensky provides a strong argument that Christian humanitarian work in South Sudan is situated within complex historical and political entanglements that are not reducible to ideological discourses of global neo-liberalism or the superiority of the global north. We extend his work by delving deeper into the internal worlds of Christian humanitarians in South Sudan, moving towards the psychic processes of humanitarians as a complement to the related work on organizations and institutions.

This work is similar to ontography, which Lynch $(2013,444)$ describes as "ethnographic investigations of particular world-making and world-sustaining practices that do not begin by assuming a general picture of the world." Borrowed from critical social studies of science and merging into anthropology and other social sciences, ontography requires researchers to take alterity seriously - to inquire into worlds rather than representations of the world or worldviews (Holbraad 2009, 81 ). We are therefore not treating our participants' accounts as moments of discourse or as products of particular epistemological and political locations, although such exploration would also yield insights. We are treating them as accounts of things that actually exist.

Attention to ontography raises the issue of sympathy or empathy with participants. We did not share many of their attitudes or opinions about topics as diverse as soteriology, gender relations, or American politics. Even in those areas where our philosophical differences from participants were greatest, however, we do not intend in this article to decompose or deconstruct their ideas. Rather we are seeking to compose or construct them - to show the deep structures of a world built out of everyday life, explicit teachings, and personal experiences. Our endeavor should not be mistaken for unqualified support for our participants' works, and does not preclude political analysis of global inequities or asymmetries of power.

As noted above, ontography concerns itself with both world-making and world-sustaining practices. Making and sustaining are interdependent practices, but for the purposes of this paper, we focus on practices that sustain. Through expressing emotions, telling stories, and describing entities, our participants work to hold their worlds together, to create 
coherence, or where coherence is impossible, to account for the disjunctures between lived experience and understandings of the world. The volatility of South Sudan and the riskiness of participants' lives required that much psychic work go into sustaining a world centered on a fundamentally benevolent God.

\section{Conceptualizing Humanitarianism Among Strangers}

We take inspiration from the work of Sara Ahmed (2000) and others on scholarship related to encountering strangers within post-colonial settings. Ahmed argues that scholars "need to consider how the stranger is an effect of processes of inclusion and exclusion, or incorporation and expulsion, that constitute the boundaries of bodies and communities, including communities of living (dwelling and travel), as well as epistemic communities" $(2000,6)$. Our work is situated clearly at the nexus of bodies and communities, some of which are located geographically within the country of South Sudan, but also located epistemically through a Christian humanitarian sense of the Christian community, a community of believers and followers of Jesus. The navigation of difference and relationality in the Christian humanitarian work of South Sudan represents a window into the world of humanitarian work more broadly throughout the global south.

What are the basic human impulses that might lead individuals to lift themselves out of more comfortable surroundings of home and community to engage with a distant other, and to sustain that engagement through times of political turmoil and personal risk? Scholarship on this basic human impulse for humanitarian work falls into several categories. The philosophy of emotions offers one way to examine these impulses. As noted by Nussbaum $(1996,28)$, "compassion, in the philosophical tradition, is a central bridge between the individual and the community; it is conceived of as our species' way of hooking the interests of others to our own personal goods." Arguing against the rationalists of modernity, who tend to discount a constructive role for emotions in public life, Nussbaum's work attempts to re-center emotions such as compassion as motivating and organizing dimensions of political and humanitarian work. In doing so, she attempts to show "that compassion is, above all, a certain sort of thought about the well-being of others." Our participants were undoubtedly compassionate in their concern for the well-being of the people of South Sudan, but their compassion sprang from a particular way of knowing the world grounded in religious conviction, rather than a humanistic way of thinking about individual and collective well-being. 
Related to this work on emotions is a second area of work on solidarity within feminist scholarship. Drawing on the idea of affective communities, Pedwell (2006) and others (see Hemmings 2012) interrogate the role of emotions as a critical element that can sustain feminist political work, specifically the notion of empathy - putting oneself in the shoes of another. In the words of Pedwell $(2006,164)$ "How can theories of empathy premised on proximity and intimacy negotiate the complex problem of 'the distant other'?" In attempting to answer this question, Pedwell explores the 'immersion programmes' of international aid workers in relation to those living in poverty and how these immersions are assumed to be an effective strategy for giving voice to the poor and making more visible (and political transparent) the needs of marginalized and impoverished regions worldwide. Through a lens of feminist theory and critiques of neoliberal political economy, she shows how this empathic approach to encountering the distant other, although often affirmed within feminist scholarship, can simply perpetuate inequality of subject positions and relations of power. In moving beyond empathy as the primary affect, Hemmings (2012) argues for a feminist politics of "affective solidarity", anchored in the experience of dissonance, frustration and rage rather than similarity and sympathy, as the ground for ethical feminist engagement with distant (and not-so-distant) others.

A third area of work involves the politics of responsibility, outlined clearly in the work of Young (2006) and others. In asking the question, how ought moral agents conceptualize their responsibilities in relation to global injustice, Young outlines a sense of responsibility through our experience within a more globally connected world. These connections are thus reconstituted through time as responsibilities and obligations. Young $(2006,215)$ states that "our responsibility derives from belonging together with others in a system of interdependent processes of cooperation and competition through which we seek benefits and aim to realize projects." In this sense, the responsibility model is highly relational but is also pragmatic and utilitarian with the realization of shared projects as a goal. An awareness of structural injustice is the foundation of this model, as individuals become aware of the ways in which they contribute to injustice and join with others to try to undo some of its effects.

Although these ways of interpreting the self-sustaining practices of our research participants offers partial insight, they remain incomplete in framing their experiences in South Sudan. Our participants did not speak in terms of responsibility for global injustice, nor, we think, would they recognize themselves in the formulations of fem- 
inist solidarity put forward by Pedwell, Hemmings and others. Although their work in South Sudan undoubtedly had powerful emotional components, affect alone did not bring them to South Sudan as Christian humanitarians. We argue that instead recognition is the primary means through which Christians in South Sudan make sense of the "other" and of the complex and dangerous world in which they find themselves. In this study of Christians in South Sudan, we sense strongly that recognition is an organizing basis for moral and ethical engagement with the unknown other. ${ }^{2}$

German social theorist Ulrich Beck (2010) describes the recognition of otherness as the guiding maxim of religious cosmopolitanism-a perspective where religious differences are recognized, but not hierarchically organized or dissolved (70). Furthermore, this cosmopolitanism is only possible when religious belief has been thoroughly individualized - where people have developed gods of their own, and recognize this reality in those around them (Beck 1999, 14; 2010). Thus, Beck discourages the "demonization" of the individualization of religion because "individualization makes it possible to practice the peaceable resolution of absolutist truths across religious frontiers" $(2010,200)$.

Much of the literature from political theory focuses on what Fraser (2003) calls the "grammar of political claims-making." Although this claims-making work explains the growth of political life in contemporary societies, it is not entirely adequate to convey the experiences of Christians working in South Sudan. Their work is unquestionably a form of politics, concerned with the distribution and circulation of scarce resources and bound up with global and local asymmetries of power. Yet these politics, as narrated by our participants, engage a

2. Recognition is a term with provenance in social and political theory. The concepts of recognition and misrecognition lie at the core of Pierre Bourdieu's theory of symbolic violence, which argues that agents often come to "misrecognize" the structural hierarchies that they are embedded as something that is "natural" (2001, 1-2). Charles Taylor (1997) draws a connection between the politics of recognition and the politics of identity that animates contemporary nation-states and identity politics. For Taylor, the politics of recognition require that all people be seen as equally deserving of rights and protections, Misrecognition, when some people are seen as more deserving of rights than others, lies at the root of political violence and oppression. Similarly, Nancy Fraser (2003) places recognition within the context of multiculturalism in the modern state. Recognition can be a mobilizing tool for communities and groups who are marginalized by the powerful. "Recognition struggles" for legitimacy and respect can evolve through dialogic models of communication and encounters, although they can also be derailed into overly simplified and hardened group identities. 
theological dimension that is not present in most studies of recognition.

To understand this dimension, we turn to notions of recognition in ways that are quite distinct from this literature in political philosophy and feminist scholarship. Rather than a grammar of claims-making, our work is focused on a realm of religious "culture work" where recognition becomes a motivation for cross-cultural interaction and humanitarian response. Within a theological sense, the idea of recognition is encoded into the gospel message; 'we are all children of God' and in this sense there is mutual recognition within a Christian community. The focus here is welcoming the stranger as a theological impulse.

We call this the theopolitics of recognition, and argue that it is a distinctive and powerful means of encountering the other, in which self-other relations are always triangulated through individualized relationships to the divine. This theopolitical work makes the stranger more recognizable, more approachable, and ultimately more coherent with their understandings of the world and their reasons for humanitarian work in South Sudan.

Triangulated relationships to the divine are repeated throughout Christian texts, with subtle variation. In the Hebrew Bible, the imperative of "welcoming the stranger" is repeated throughout the history of God's chosen people as wanderers, sometimes strangers in a strange land who encounter strangers during their travels, and sometimes as the inhabitants of a territory who are enjoined to provide welcome and hospitality to those whom they meet as a religious duty. The motif of the stranger who turns out to be not so strange-who is actually a lost family member, a messenger of God, or someone who was missing but is now found - is a reminder to treat "others" with kindness, because the "other" is in fact very close to the self, with the link between other and self being God.

In the New Testament, the early Christian community scattered across the ancient world is reminded that they should see one another as fellow children of God, that they should recognize in one another the same divine presence. Caring for one another, and for the rest of the world just as God cares provides a sort of theological filter for politics on large and small scales. An ethics probably best exemplified in the Parable of the Good Samaritan where Jesus extends the definition of "neighbour," which one must love "as yourself," to include one's traditional enemies (Lk 10: 25-37). Beck (2010) described this "com- 
passion" for others_-it's "imitatio Christi" — as an essential component of Christian cosmopolitanism (101). ${ }^{3}$

These theological approaches also extend to notions of recognition in the work of interreligious theology. Leirvik (2006) for instance offers a concept of recognition in this context that acknowledges "something that may be distinctively unfamiliar but is still worthy of appreciation" $(2006,283)$. In this sense recognition includes two elements: rediscovery and appreciation. In making this argument, he notes that "for theologians who want to engage in dialogue the first impulse is often to look for resemblances and ways to cross the distance" (285). Highlighting the importance of resemblances (or lack thereof), feminist theologians such as Gebara (2008) track the challenges of feminist theology against an institutionalized church that remains resistant to change and to the recognition of equality between humans in particular.

Although our focus is not interreligious dialogue, the impulse toward recognition (and misrecognition) is consistent with ways in which our research participants understand and encounter the other in South Sudan. This perspective reflects the tendency of monotheistic religions to "build bridges" between those recognized as fellow believers while "opening chasms" with those deemed non-believers - a characteristic that both facilitates and hinders religious cosmopolitanism (Beck 2010, 52). Through its ongoing attempts to foster a universal church, Beck argues that Christianity has a particular cosmopolitan quality that has contributed to its success. That said, for Beck, Christianity does often come-up short of real cosmopolitanism because Christian universalism still implies a separation between believers and non-believers. He points out that the God of Christian universalism, which encourages "peace" amongst fellow Christians, is also the violent God of crusade and colonialism $(2010,160)$.

3. Recent research on religion and charitable giving further elucidates this empathetic and prosocial theological imperative (Bowen 1999; Forbes \& Zampelli 2013; Reitsma et al. 2012; Schnable 2015; Sarglou et al. 2005; Turcotte 2012). For instance, non-fundamentalist members of religious groups tend to respond less aggressively when confronted with "indirect non-physical aggression" from others. Religious Americans are more likely to help a family member in need, and their peers are more likely to consider them prosocial and that this perception of being "altruistic" was linked? to a religious person's self-perception (Sarglou 2005, 342). Moreover, a study of charitable giving in the United States found that church attendance and greater participation in church activities were correlated with giving to both secular and religious organizations (Forbes et al. 2013, 2487). In Canada, while religious Canadians give $71 \%$ of their donations to religious organizations, they give more to secular organizations than non-religious Canadians do (Turcotte 2012, 28-29). 
Through a blending of our participants' insights involving the affective terrain, prosociality, empathy, ethics of care, and recognition within Christian community, we examine the navigation of difference and relationality in our case study material. One outcome of our work involves a broader sense of what motivates Christian humanitarianism, including the modes and means of relating and maintaining distance with the people they encounter while in the field and the general contexts they find themselves situated. We also identify a field of political work, where efforts to help and to make things better in South Sudan are almost entirely located at the individual level. With a focus on endogenous conditions of human flourishing, and the need to change 'hearts and minds' in particular, other realms of politic work remain sidelined. These other realms of political work may easily include geopolitical concerns regarding prominent issues like resource exploitation and corruption, weaponization, and related conflicts.

\section{Context And Methods}

South Sudan is the world's newest nation, as of 2011, and one of its poorest. Despite vast reserves of oil, it remains impoverished and devastated by four decades of violent conflict. South Sudan became independent from the Republic of Sudan in 2011, yet the anticipated "peace dividend" failed to materialize. Approximately $90 \%$ of the population lives on less than \$US1 per day (Jauhari 2010), and severe food insecurity is estimated to afflict between $16 \%$ and $37 \%$ of the population (SAS 2012). South Sudan is heavily dependent on international non-governmental organizations (INGOs) (Conway 2013; Kevany et al. 2012). Martin and Mosel (2011) estimate that over 700 INGOs have been active in the country since independence, and Grant and Thompson $(2013,219)$ describe an "enormous INGO apparatus [which] was put in place to support the newly formed government".

Of note for our project, South Sudan has been of great importance to evangelical Christians globally, particularly in the United States (Agensky 2007; Huliaras 2006; Clarke 2007; Gerhardt 2008). The very existence of South Sudan as a country has been attributed in large part to the advocacy of global Christians, who provided diplomatic, financial, and possibly military support (Hertzke 2004). The "Lost Boys"- - youth who were forced to flee to avoid conscription and who resettled in the United States and Canada, often with sponsorship from churches-added to evangelical interest in the country. The proliferation of FBOs in South Sudan is a result. 
This paper draws from interviews conducted with 30 individuals who were working or had worked in South Sudan in 2014 and 2015. Interviews were carried out in person $(n=15)$ in Juba South Sudan, Calgary Alberta, Grand Rapids Michigan, and on Skype $(n=15)$. The interviews typically lasted between one and two hours, and were taped, transcribed and coded by the authors. Participants were assigned pseudonyms and some details have been changed in order to preserve personal and organizational anonymity. We found our participants through networking and personal contacts stemming from our two visits to South Sudan in 2012. We said that we were looking for people who would be willing to discuss how their faith shaped their work in South Sudan and that we were seeking to understand how religious values and worldview enabled some forms of humanitarian action while precluding others. In addition to formal interviews, we also sat in on group discussions and meetings, and interacted informally with people from the world of faith-based organizations, both in South Sudan and in North America. Our participants were unfailingly generous and thoughtful in their willingness to talk to us about their experiences in South Sudan. ${ }^{4}$

4. The interviews typically lasted between one and two hours, and were taped (with participants' consent), professionally transcribed, transcribed and coded by the authors. We began by searching the transcripts for information about motivation and commitment to religiously-based work, but soon expanded our reach to encompass other things that struck us in the conversations, such as temporality, discernment, skill, or hope. Participants were assigned pseudonyms and some details have been changed in order to preserve personal and organizational anonymity. We had ethics clearance from the University of Alberta Research Ethics Board for qualitative and small-n research.

Our participants were self-described Christians with active faith lives. Their denominational identities varied - some were closely tied to a particular church while others were not. Some came from the Reformed Christian tradition, which emphasizes service and obedience to God's will, while others were from a more Evangelical background which stresses personal relationships with Jesus and attentiveness to the movements of the Holy Spirit. Some identified themselves with labels like 'evangelist' or 'missionary', and saw their work in South Sudan as promoting the spreading and deepening of Christianity, while others rejected the "missionary" designation and saw their work as service which was motivated by Christian values, but did not include proselytizing. None were Catholic, Orthodox or Pentecostal. Our sample thus represents a range of Protestant variations.

We were able to build building credibility and rapport through our own 'missionary DNA', with parents or grandparents who devoted much of their adult lives to spreading Christianity and serving missions in the global south. We have also, at different times, been active members of mainline 
The historical moment in which we conducted these interviews is noteworthy - we began formal interviewing in the aftermath of the December 2013 upsurge in violence and conflict which moved the country back into civil war. For our participants, this meant that projects they had spent years working on were suspended or came to abrupt ends, and many of them saw their Sudanese friends exiled or severely affected by the war. In this context, themes of despair and hope permeated the conversation, as the future for South Sudan looked bleak.

\section{ReCOGNITION}

So, when I was flying over on the plane, I swear the tallest man in the world sat next to me and I told him he could have the aisle seat but he said the window seat was fine, and his legs stretched all across me into the aisle, he was so tall. So, my first impression, one of my good friends back in the US is from Zambia and when I mentioned I was going to South Sudan, she started laughing and she said "South Sudan, they are the darkest complected [sic] Africans on the continent, they have very, very dark black skin and you are one of the palest Americans." And she said this is going to be quite a contrast. And I'm short too, I'm five one. And she was right, they're very tall and at first, I was like oh my goodness everyone is towering over me and I stand out like a sore thumb. But also, my impressions of the people, my co-workers, they've become like family, and really from the first day there they were calling me sister and always smiling and it was a very good sense of community in the work environment and it really contains to be that way. (Laura)

Protestant churches in Canada. We were thus able to 'speak Christian' (Borg 2011), and to pick up on phrases, metaphors and concepts in conversation which were linked to Christian theology or the Bible. We presented ourselves to our participants foremost as researchers, however, not as fellow believers. They were candid about sharing their views with us, even without the assurance that we believed the same things they did.

Most of our participants were career humanitarians, who had worked in nonprofit organizations, often beginning with secular organizations before moving into the Christian ones. They worked for organizations which ran the gamut from small groups of 'freelance altruists' Watkins and Swidler (2013) to large multinational NGOs with decades of history in the region and thousands of employees. All the organizations were explicitly Christian in orientation. A minority of these organizations engaged in overt proselytizing, through preaching and other activities intended to convert people to a particular form of Christianity, while the majority practiced "faith in action", carrying out humanitarian work out of an ethos or compassion or solidarity. 
Laura's story encapsulates some of the themes of this article: the initial strangeness of South Sudan and its people (here manifested as the "tallest man in the world"), the mutual, if slightly awkward, good intentions of the encounter, in the form of offering each other the aisle seat, and the ongoing experience of difference between short white people and tall black ones, on which a commonality of emotion is superimposed, in the form of co-workers who are "like family" (but yet are not exactly family). In this paper, we present a group of people like Laura, for whom the problem of how to relate ethically to the distant or not-so-distant stranger is mediated by a specific set of values and ontological presumptions, generically known as a Christian or biblical worldview.

Many people across the world are guided in their actions by religious commitments, but this particular group of people provides a unique opportunity for advancing theory about ethical relations to the other. These evangelical humanitarians in South Sudan have complex affective and moral lives, played out on terrain that is both strange and strangely familiar. They encounter unexpected physical, geographical, cultural, and interpersonal challenges during their work in South Sudan, yet these encounters are interpreted within the epistemic community of worldwide Christianity, which provides central interpretive devices as well as material rituals and a sense of belonging.

Despite theological differences within our sample, certain tenets of Christianity are constant. Of particular relevance to this article is the idea of "embracing the stranger". Many scriptural passages, with which we expect our participants would have been familiar, emphasize the importance of welcoming and providing succor to strangers. For example, Deuteronomy 24:17-18:

You shall not deprive a resident alien or an orphan of justice; you shall not take a widow's garment in pledge. Remember that you were a slave in Egypt and the Lord your God redeemed you from there; therefore I command you to do this. ${ }^{5}$

Similarly, the New Testament contains several accounts in which Jesus appears in the form of a stranger to his disciples, who realize his true nature when he speaks of his heavenly father. The early apostolic writings to the scattered Christian communities of the Mediterranean admonish Christians to embrace and love each other, despite their ethnic, linguistic, and cultural differences, because they are followers of the same God. These injunctions are not merely reminders to be nice to other people,

5. All Biblical citations are taken from the New Revised Standard Version (NRSV). 
they are also statements of an ontology in which the self and the stranger become mutually intelligible because of their shared relationship to the divine. This recognition entails action — radical hospitality—and creates moral claims.

These Christian injunctions are the ethical framework that mediate our participants' encounters with a "distant other". The importance of "embracing the stranger" provides evidence of a mode of relation based on recognition, as distinct from the documented modes of solidarity, responsibility, or emotional empathy that compel and animate humanitarian effort. Faith-infused recognition - seeing and knowing the stranger as a person with the same relationship to God as oneself-is not only a form of relation but also an affective mode, prompting emotions of concern, affection, and sometimes grief.

Evangelical humanitarians say that their desire to engage with South Sudan and to be present with people there is both motivated by and experienced as a recognition of the other as a "child of God." Recognition is not simply an experience that one lives through, it is a driver of actions and commitments. Sam pointed to the productive powers of this mode of recognition by saying that for him, the ability to recognize that he and the South Sudanese shared "the human position before God" enabled him to relate to his local counterparts in a more open and constructive way.

And I think just for myself personally, just looking at someone it's easy to say this person or that person, he's just part of the atrocities that are going on, but I think from a Christian perspective recognizing the human position before God and how you're not in some ways so much better or so much worse, but maybe you can see that person as someone before God. It helps in how you approach people and your attitude, not slipping into cynicism. (Sam)

Bryce, one of the most theologically well versed of our participants, linked this recognition of the other to a recognition of one's own true nature. The other is recognized as no different from the self, united by a shared relationship to God:

Our unity in belief that we are all God's children, made in God's likeness, and all deserve to have that dignity about us and our tribal differences, our economic, cultural, political, racial differences should not stop us from caring for one another and acting in this way. ... If you're always working with the other, you get tired. You get tired. (Bryce)

For Brenda, seeing the South Sudanese as fellow children of God was not just a religious twist on solidarity or empathy, but a relational stance 
in which God was the ground of connection. She was adamant that she "did not believe in humanity" - she did not believe that people, left to their own devices, would treat each other kindly or justly. It was only through the power of God's presence that people could come to recognize one another as fellow children of God and to act on that basis. Brenda was disheartened by secular humanitarianism, which she saw as an enterprise that was fundamentally hampered by its lack of a theopolitics of recognition and was thereby vulnerable to being hijacked by opportunism and political agendas:

Brenda: I don't believe in humanity, I love human beings and having compassion and all those things, but I know that we can't trust them. We can trust God to change the situation but we can't trust even democracy to make the world a better world. ...

Amy: Could you talk more about what you see as the difference between faith-based NGOs and secular ones?

Brenda: [The difference is] about how we see the other, as a poor person who can't do anything for themselves or if we see them as child of God that was created in his image. So that would be the biggest thing (emphasis added).

Brenda believed that the work of faith-based organizations is to improve the world not through targets, projects, and quotas but through individual hearts and minds. She was critical of organizations which set out to "save the world", because only God could do that. Therefore, by recognizing that everyone has something of God in them Christian humanitarians might be able to "leave a trail in people's hearts" through personal relationships.

More than achieving something, we want to leave a trail in people's hearts. ... And maybe seeing [humanitarian work] not as a business but as changing the world, not saving the world but changing the world. Changing the hearts of people around us I would say.

For Sam, building personal relationships with others that were rooted in a shared sense of belonging to God defined his work in South Sudan, which he understood as serving others. His conviction that this was the right way to be in the world while in South Sudan grew over the course of his work there, so that at the point when we spoke to him, he understood the building and maintenance of God-centred relationships, which he defined as service to God, as a constant effort, not merely his paid job. He contrasted the "get this done" attitude of most development work 
with what he saw as the much more challenging and difficult work of relating ethically to others:

Sam: Even when you started with the idea of wanting to serve [at the beginning of his contract] I think it was still more about me than about serving when I look back. So just keeping the attitude of the reason you're here, Christ first and what it really means to be serving. And something that really struck me, you go in with the attitude of get things done, get this done .... So you have to remember that you're serving everybody. ... I think it's a relationship that you're building that's important and that yeah, you're serving everybody. That extends even to your own team members because you're in such tight quarters and such a different world. You're plucked from everything you know and you're always serving. You don't ever go home and close the doors and say I'm in my space and I'm doing this. In my opinion you're always serving from the time you got on the plane and left home. And it helps, the attitudes you have and how you interact with people when you're carrying out the work 24 hours a day, you're always doing it.

Amy: You can't put it aside and say I'm done work for the day.

Bryce, Brenda, and Sam present the first of two of the primary ways in which faith-based humanitarians recognize the people they "serve:" through a recognition of a shared humanity rooted in the theological conviction that we are all created in the image of God and an ethical obligation to ensure human dignity; and by recognizing the shared Christian affiliation of the South Sudanese. These two forms of recognition are difficult to disentangle and often imply each other.

\section{Emotional Landscapes of South Sudan}

For our participants, South Sudan was both home and not-home. Although some rotated in and out of the country on short-term contracts, many, particularly the most religiously motivated, made conscious efforts to make South Sudan into a home, a place of deliberate familiarity. Some were inspired by their ideas of missionaries of earlier generations who lived in communities for years on end, while others wanted to avoid living with a sense of unsettledness and temporariness. Susan worked hard to make her living space feel comfortable, rather than a temporary bivouac in an alien environment: 
I call South Sudan home. My kids aren't Sudanese in the sense that they're not tall and black, but they are South Sudanese in the sense that that's where they're going to start the first years of their lives. We have [longterm] contracts and I think that really makes us feel settled. And then we shift a lot of things with us, so we have a home as opposed to people who live in hotel rooms and like little units. I mean it's a very simple home, it's just a prefab container like everyone else but we have our own couches and we brought our Christmas tree and [children's toys] outside and pictures on the wall and pretty lamps and nice curtains. (Susan)

Being at home in South Sudan requires more than just books and Christmas trees. Claiming South Sudan as home, rather than as a strange and alien land, meant navigating a complex affective landscape, marked by poles of hope and fear. While participants saw many examples of hope and regeneration around them on a day-to-day basis, they were also aware of the broad-scale, birds'-eye view of the country that tilted towards nihilism and disaster. Navigating between these poles was a challenge for participants who wanted to claim a home in South Sudan, rather than being simply disdainful of the country. Pamela described the challenge when she went back to her country of origin to talk about her work in South Sudan.

And you want to share the reality and how hard it is but at the same time I don't want to talk bad about the country I live in, and want people to see the beauty as well so trying find the balance between showing the brokenness but not dishonouring this culture that you're living in and calling home. So I'm conscious when I'm sharing is to try to paint a picture that encapsulates both the beauty and the desperation. And then the fact that we can do something about it. (Pamela, emphasis added)

Christine, who had experienced situations in which her life was threatened, oscillated between seeing South Sudan as a place of chaos and anarchy and a place where hope might flourish. Her belief in God allowed the "hopeful" framing of South Sudan to win out, enabling Christine to remain in very trying circumstances and focus on the "potential for growth."

Robert and his wife provided a strikingly literal account of the emotional landscape, as they negotiated the poles of fear and hope within their marriage. Robert traveled frequently to a remote location, which he described warmly as a place where good things were happening and where he was coming to feel at home, exemplified by small gestures of kindness of the people of the area. He described himself traversing this landscape, walking for miles through tall grasses surrounded by "guns 
and stuff" but feeling no fear. His wife, however, saw the same terrain as a location of fear, an alien country in which her husband was in grave danger. The US Department of State, which classified South Sudan as a very high-risk destination, provided one way to interpret this strange land, and the Christian faith she shared with her husband, which emphasized hope and redemption, provided another.

One thing that for me is really difficult, [is that] because my wife has an incredibly high level of fear. She gives it to the Lord every day, but she really — how do you wash or scrub that out of your brain because you know, you go to the US Department of State to register, and they say, don't travel there. We're taking our people out, they're traveling in armoured vehicles, and it's like, what? ... She was going crazy with fear of what might happen to me. ... [But] ...I felt very safe, ...I never ever felt any fear which is really I think that the peace of the Lord that would - that was with me. (Robert)

Faith enabled our participants to manage the oscillation between hope and fear, and thus to avoid the traps of cynicism and despair. The danger of falling into cynicism and a disparaging attitude towards South Sudan and its people was described as an affective trap, not unlike the "slough of despond" in Pilgrim's Progress.

Navigating the affective landscape of South Sudan, as well as engaging in theopolitics of recognition, was made easier by loose networks and ties amongst expatriate Christians working there. Many participants referred to the friendships they made and the worship they shared as something that enabled them to keep their bearings in South Sudan, to remain true to the way they understood Christianity and to the selves they wanted to bring to their encounters with the South Sudanese. Christian communities were not only familiar reminders of the global Christian world to which they belonged, they were also part of making South Sudan feel like home. These mundane commonalities can help aid workers build solidarity with the strangers in their new surroundings (Datta 2013, 96). Richard credits his Christian friends in South Sudan and abroad with helping him to remember that "God is not done with South Sudan":

Being around friends who share that conviction, who share a belief that God is not done with South Sudan, it's significant. ...It provides strength to carry on and persevere with when it would appear everything is exhausted or at least that it makes much more sense to run away. (Richard, emphasis added) 
In a similar fashion, Linda tapped into Christian communities to bolster her commitment to being in South Sudan, and to keep working in what she understood as a Christian way, relying on God's guidance and providence even when human efforts seem inadequate. She contrasts faith, which gives her friends to cope with South Sudan, with the coping strategies chosen by non-Christians, such as drinking:

[T]he few [non-Christian people] I met had a much stronger drinking culture and then feeling that people needed a drink in order to be able to cope whereas generally speaking I think Christians tended to be healthier because we're there with God and in his strength and with the help of the holy spirit and there's less pressure on us in the sense of we know it's not all based on humans strength anyway and have that paradigm of where our own works fit into the greater scheme of things. ...I don't think I could have been in that environment without faith because I just wouldn't have been able to last. (Linda)

For Linda, religion appears to function as a palliative - in an almost Marxist sense. ${ }^{6}$ Linda's faith works as a socio-medicinal remedy that relieves the emotional pain caused by the structural situation she finds herself embedded while in the field. Thus, somewhat ironically, religion helps her to disconnect from the overwhelming structural pressures around her, which enables her to continue working to address some of these very same structural issues.

\section{RECOGNITION AS "Boundary WORK"}

As mentioned previously, our participants recognized the persons those around them in two primary ways: a shared humanity and a shared affiliation. Linda's story brings us to the latter important mode of relationality. This mode was the use of faith, and specifically the faith-inflected stance towards working with the South Sudanese people, as a form of "boundary work", differentiating faith-based organization from secular ones within the constellation of humanitarian organizations in South Sudan (Tilly and Tarrow 2007).

Participants constructed an identity as Christian humanitarians partly through contrast to the secular development and relief organizations around them. Those who were based in Juba lived in a veritable alphabet soup of relief and development, including WFP, CARE, UNHACD, PSI, CFB, DFID and many more. Although they worked closely with their

6. Social theorist Karl Marx argued that religion was an "opiate" that prevents people from being able to comprehend their own oppression (Marx 1844). 
secular counterparts, they also set themselves apart, which was made possible through a mode of relating ethically to the South Sudanese that they identified as specifically Christian. They repeatedly emphasized the importance of one-to-one, person-to-person connections with South Sudanese people, in distinction to the depersonalized, distanced bureaucratic imperative of large secular organizations.

So we can measure our impact through, you know, the lives touched in treatments received, you know, the surgeries, number of people that have been ministered to from a Christian standpoint in the daily devotions to the patients waiting for the clinic. We can measure an impact that way. ... They [secular development organizations] have no idea what their impact is other than the fact that yeah, we had $\$ 100,000$ to spend and we spent it and we came in under our timeframe. (George)

\begin{abstract}
... And things like truthfulness, like every organization is hopefully against fraud for example. But really recognizing [the value of truthfulness] not because it's an organizational decision but because it's the way that God wants us to live and a biblical decision as well. We would have devotions three times a week in South Sudan and worship together and pray together, and in decision making prayer would be much more of an element than it would be in secular organizations (laughs). (Linda)
\end{abstract}

The emphasis on one-to-one personal relations was not only a way of setting Christian organizations off from secular ones, it also enabled Christian humanitarians to understand their own work as worthwhile and important if they were able to establish personal relationships with individuals, even when the bigger picture was bleak. The work of recognizing the other as a fellow child of God was work that was worthy in its own right, even if material and measurable successes were scarce. This emphasis on relationships for their own sake was especially important in warding off a sense of futility post-2013. Several participants told us that while they did not know what the outcome of their projects might be, but they knew that the prayerful connections and friendships they had made while serving the South Sudanese were intrinsically valuable within a Christian context.

James, who had worked for a secular organization, believed that faith-based ones offered the best chance at respectful, dignified connections to local people, rather than treating them as needy mouths to fill or sick bodies to fix. He saw South Sudan's issues as profoundly relational, but not simply limited to bad relations between groups in conflict — rather, he saw the relationship between individuals and God as being in need of repair, a relationship in which the white people partook on the same 
basis as well as the South Sudanese. Rather than simply handing out material goods, James saw himself "turning around" to the South Sudanese to express God's power to heal broken relationships.

\begin{abstract}
When we talk about our neighbour and expressing love and the grace that God has given us, that recognizing that and placing the expectation that that is expressed, either within your team or in the community where you're working, to me it's such a stark contrast with the [secular] agency where I was working previously where you just caught up in the business of it all and the objective becomes getting the money to keep the office open and meeting your fundraising targets ... That being said I've seen a lot of activities we've done that have not worked. But I think that emphasis on putting God at the centre, recognizing his role in your life and the organization's life and then turning that around and expressing it, either in the devotionals that we have three times a week or in just the regular practice of prayer before and after meetings or even just being an expression of God in everyone you're meeting, those are different elements I have not seen or experienced in more secular or traditional development agencies. (James, emphasis added)
\end{abstract}

For Richard too, personal relationships with the people amongst whom he worked were closely connected to his own relationship with God. Richard worked with street children, who could be obstreperous and dishonest and often challenged his patience. Richard felt called to emulate God, who forgave and was merciful towards him, which imposed on him the duty to show similar mercy to irritating street children. God was present as a third person in Richard's relations with these children:

I don't know how you continue to motivate yourselves aside from the fact that we have a core belief that these children matter to God and also that God has treated us in a way that we don't deserve, and we can be a means by which they can be shown care and find relief and restoration no matter how long it takes, we might continue to show grace and mercy. (Richard, emphasis added)

\title{
Forms of RECOGNITION
}

Participants' encounters with South Sudanese people were experienced within a mode of theological recognition, but these encounters were not homogenous. Some participants spoke of friendships that had developed over years, while others spoke of moments of connection and a sense of being together. Variations on the theme of recognition included the ex- 
perience of being inspired or transformed by encounters with the South Sudanese, as well as the more ethically complex experience of "teaching" or "enlightening" the South Sudanese people.

Brenda expressed a sense of commonality with the South Sudanese because of their shared Christianity, but she perceived the South Sudanese as more faithful and more committed to God's will than most North American Christians. This identified commonality is analogous to Leirvik's (2006) two-part definition of recognition (discovery and appreciation) where the first impulse is to seek out resemblances with the distant other. While the South Sudanese might not have had the biblical education of many American evangelicals, they had a relationship to God which went even deeper. When asked what she would like to have told her younger self upon first arriving in South Sudan, Brenda said

I would say you're going to be encouraged by the Christians of South Sudan. I have been inspired by some of those people who went through terrible things and taught me about forgiveness, like if you lose your wife you need to forgive because this is what Jesus is asking from you. So if you think that it has a deeper meaning, then you see people killing each other and you say stop killing each other because that will make the world a better place, but when you have this response from the heart. I do believe that hope for South Sudan is coming, from Jesus but also from some very strong Christians who put the Bible into practice, including forgiveness. Forgiveness in this context is mind-blowing somehow. (Brenda)

Similarly, Laura expressed a sense of uplift and transformation through the faithfulness of her South Sudanese colleagues, even as the country moved towards war and political collapse:

I am just in awe at their faithfulness, the believers in this country and a lot of our coworkers that believe, they are constantly in tears and mourning for peace in the hearts of the leaders, for peace in the hearts of the South Sudanese, for peace in their families, they continually pray and mourn for peace. ...And I think that has made an impact in my life and how I see things and sometimes I'm so short-sighted when I think about all the things I've haven't accomplished. (Laura)

For other participants, however, South Sudanese Christians were less an inspiration than an opportunity to teach. These participants understood their work in South Sudan as sharing the good news and doing the work of God, but also as the transfer of correct values and ways of being from North America to Africa. More conservative participants often expressed the view that Christianity in South Sudan was "a mile wide and an inch 
deep", and sought to transfer more authentic ways of being Christian. Their accounts hewed closely to old-school missionary impulses, in which enlightened white leaders brought religion to the unchurched or semi-churched.

Al, for example, provided a detailed account of how an American friend of his had taught a local man about the superiority of bidirectional exchanges of resources over one-way gifts. The visiting pastor modelled in microcosm a worldview based on self-sufficiency and market exchanges, within the context of shared Christianity.

[A visiting pastor from the United States] came to see me the day before we were going to leave and he said "Al", he said, "I've just grown so close with this teenage young man." And he said, "I really want to give him my bible because we've had a good time talking about God but" he said, "you mentioned not to give things." And so I says, "Well, Ted, I tell you what. It's certainly great to give him your bible but," I said, "we don't want to create dependency so why don't you consider trading something he has for your bible?" And he did. So he had that black and white necklace, what you can call those things. He had that on. So he said to him before he left, he said, "I really like your necklace. Would you be willing to trade that for my bible?" And boy, that guy got that necklace off so fast. He wanted the bible. But at least he had to give up something to get something. (Al)

In Al's story, the pastor and the young Sudanese man shared a faith, symbolized by their attachment to the Bible, but this shared faith did not put them on an even playing field. Under the guidance of $\mathrm{Al}$, a more experienced evangelical, the American pastor teaches the young Sudanese man appropriate "habits of the heart" (Bellah 1985). Penny took a similar approach in her work with a church in South Sudan, asking them what the Bible means to the children involved and teaching them "how God wants the bible applied to [their] life, what does the Story mean in Sudan today." Similarly, although less overtly, Rachel saw her work in South Sudan as a matter of "chang[ing] people's hearts". God gave her the ability to recognize the divine presence within the people of South Sudan, but also gave her and her American colleagues an understanding of God's will to convey to the Sudanese:

We can help change people's hearts if we can help them look at life and the world in a different way, maybe. Maybe down the road, the next generation or person by person, that will sort of change slowly. And so I think it's not just about [sanitation] programs and handing out food or growing vegetables, it's a heart issue that's in creating the [peaceful] dynamics that we've not seen in South Sudan. (Rachel) 
These didactic impulses are linked to something that we see as a limitation of the theopolitics of recognition explored here. Focusing on encountering the other on a one-to-one individualized level, whether the experience is one of mutual transformation or of didactically teaching others, may direct attention away from larger structural problems. The macroeconomic and political challenges facing South Sudan are complex and daunting, so it is perhaps not surprising that our participant did not see themselves engaging with oil economics, great-power positioning in central Africa or small arms flowing from Ethiopia into South Sudan. Nonetheless, these topics almost never came up in interviews, as people reflected on their journeys through the affective landscapes of South Sudan. Even when we explicitly asked what they saw as the greatest challenges facing South Sudan, answers were more likely to skew towards the transformation of hearts and minds rather than political or economic dynamics. The theopolitics of recognition may close down certain forms of understanding and acting, even as they enable other forms.

It also makes visible the limits of this form of recognition and in turn Christian cosmopolitanism. Beck warns of the "chasms" Christianity often builds between believers and non-believers (Beck 2010, 52). This theopolitics of recognition may only be taking place in situations where Christian universalism applies - where people are meeting fellow believers in a Christian god. Our work in South Sudan begins to reveal the boundaries and overlap between universalism and cosmopolitanism (between relationships built on the recognition of a shared humanity vs a shared affiliation), and the intricate relationship between individualism and religious cosmopolitanism.

\section{Conclusion}

What does a theopolitics of recognition actually do in South Sudan? Our study consists of people talking about what they do. We did not actually observe them at work, so we cannot say to what extent their talk maps onto their actions. We cannot assess whether a theopolitics of recognition makes faith-based work "better" or "worse" than more secular work, because all forms of encountering "the other" are fraught with particular hazards. What we have done, however, is to illuminate the ontography and the deep structure of thought and affect at work when evangelical humanitarians talk about what they do. Their thoughtfulness and selfscrutiny belies the stereotype of the rigidly unreflective "white saviors" imposing their will on Africa.

Although we cannot gauge the material consequences of this theopolitics, we have described the psychic work it does. Holding this 
understanding of encounters between self and other enables our participants to navigate the affective landscape of South Sudan, moving between hope and fear. It also enables them to create an identity, based on shared understandings of why Christians from the global north might find themselves in South Sudan, and in distinction from the more secular NGOs. This politics of recognition enables participants to see success in the nurturing of individual relationship and service, even when their projects and operations go awry. This emphasis on regarding the other through a shared relationship with God also produces particular understandings of the other, as sources of inspiration and transformation, but also, and more problematically, as people in need of teaching or training.

The theopolitics of recognition constitute an understudied universalist and potentially cosmopolitan mode of relating to the "other" within faith-based humanitarian enterprises. Faith triangulates humanto-human relations through a shared connection to an individualized divine presence, a form of relationality which is not captured by the analytical frameworks centred on emotion or solidarity or responsibility or prosociality that are dominant in the social scientific literature on humanitarianism and religion. Centering theology within world-making and world-sustaining practices also enables faith-based humanitarians to inhabit an affective world in which fear, hope, and love intermingled. It also enabled humanitarians to constitute themselves and their organizations as fundamentally different from secular ones. These practices have both intellectual and practical implications for the study of international development.

\section{REFERENCES}

Ahmed, S. 2000. Strange Encounters: Embodied Others in Post-coloniality. New York: Routledge.

Agensky, J. C. 2013. “Dr Livingstone, I Presume?”: Evangelicals, Africa and Faith-based Humanitarianism. Global Society 27(4): 454-74.

Anderson, BP. 2012. Chosen Nation: Scripture, Theopolitics, and the Project of National Identity. Portland, OR: Wipf \& Stock.

Beck, U. 1999. World Risk Society. $1^{\text {st }}$ edition. Malden, MA: Polity.

2010. A God of One's Own: Religion's Capacity for Peace and Potential for Violence. Translated by Rodney Livingstone. $1^{\text {st }}$ edition. Cambridge, UK ; Malden, MA: Polity.

Bex, S., \& S. Craps. 2016. Humanitarianism, Testimony, and the White Savior Industrial Complex: What Is the What versus Kony 2012. Cultural Critique 92(1): 32-56. 
Bourdieu, P. 2001. Masculine Domination. Palo Alto, CA: Stanford University Press.

Borg, MJ. (2011). Speaking Christian: Why Christian words have lost their meaning and power-And how they can be restored. Harper Collins.

Bowen, K. 1999. Religion, Participation, and Charitable Giving: A Report. Volunteer Canada \& The Canadian Centre for Philanthropy. http://www. imaginecanada.ca/sites/default/files/www/en/giving/n-vcl-en.pdf (accessed 18 October 2017).

Clarke, G. 2007. Agents of Transformation? Donors, Faith-based Organisations and International Development. Third World Quarterly 28(1): 77-96.

Chouliaraki, L. (2010). 'Post-humanitarianism: Humanitarian Communication Beyond a Politics of Pity'. International Journal of Cultural Studies, 13(2), 107-126.

Conway, G. 2013. Lessons on Transition for South Sudan. Humanitarian Exchange 57 (May).http://www.odihpn.org/humanitarian-exchange-magazine/issue-57/lessons-on-transition-in-south-sudan (accessed 4 July 2014).

Datta, R. 2013. Mundane Cosmopolitanism, Mobility, and Social Justice: A NeoDurkheimian Approach. In Mobilities, Knowledge, and Social Justice, edited by S. Ilcan, 76-102. Montreal \& Kingston: McGill-Queen's University Press.

Forbes, K \& E. Zampelli. 2013. The Impacts of Religion, Political Ideology, and Social Capital on Religious and Secular Giving: Evidence from the 2006 Social Capital Community Survey. Applied Economics 45 (17):2481-90. https://doi.org/10.1080/00036846.2012.667555.

Fraser, N. 2000. Rethinking Recognition. New Left Review 3: 107-120.

Fraser, N. 2003. Rethinking Recognition: Overcoming Displacement and Reification in Cultural Politics. In Recognition Struggles and Social Movements: Contested Identities, Agency and Power, edited by B. Hobson, 21-32. New York: Cambridge University Press.

Gebara, I. 2008. Feminist Theology in Latin America: A Theology Without Recognition. Feminist Theology 16(3): 324-331.

Gerhardt, H. 2008. Geopolitics, Ethics, and the Evangelicals' Commitment to Sudan. Environment and Planning D: Society and Space 26(5): 911-928.

Grant, R. \& D. Thompson. 2013 The Development Complex, Rural Economy and Urban Spatial Economic Development in Juba, South Sudan. Local Economy 28(2): 218-30.

Halvorson, B. 2012. Woven Worlds: Material Things, Bureaucratization, and Dilemmas of Caregiving in Lutheran Humanitarianism. American Ethnologist 39(1): 122-137.

Hemmings C. 2012. Affective Solidarity: Feminist Reflexivity and Political Transformation. Feminist Theory 13(2): 147-161. 
Hertzke, A. 2004. Freeing God's Children: The Unlikely Alliance for Global Human Rights. New York: Rowan and Littlefield.

Holbraad, M. 2009. Ontography and Alterity: Defining Anthropological Truth. Social Analysis 53(2): 80-93.

Huliaras, A. 2006. Evangelists, Oil companies, and Terrorists: The Bush Administration's Policy Towards Sudan. Orbis 50(4): 709-724.

I'Anson, C., \& G. Pfeifer. 2013. A critique of humanitarian reason: agency, power, and privilege. Journal of Global Ethics 9(1): 49-63.

Jauhari, A. 2010. South Sudan: A fledgling nation. International Journal of Business and Social Science 1(3):167-71.

Kevany, S.; A. Hatfield, N.G. Workneh NG, B.A. Durrani, Y. Bekele, U. Khan, K. White, R. Myrick. 2012. Diplomatic and Operational Adaptations to Global Health Programmes in Post-conflict Settings: Contributions of Monitoring and Evaluation Systems to Health Sector Development and 'Nation- building' in South Sudan. Medicine, Conflict and Survival 28(3): 247-262.

Leirvik, O. 2006. The Double Sense of Recognition in Interreligious Theology. Norsk Tidsskrift for Misjon 60(3/4): 283-296.

Luban, D. 1996. A Theological Argument Against Theopolitics, 16 Report from the Institute for Philosophy \& Public Policy 16(1): 10-14.

Lynch, M. 2013. Ontography: Investigating the Production of things, Deflating Ontology. Social Studies of Science 43(3): 444-462.

Martin, E. and I. Mosel. 2011. City Limits: Urbanisation and Vulnerability in Sudan, Juba Case Study. London: Overseas Development Institute.

Marx, Karl. 1844. Towards a Critique of Hegel's Philosophy of Right: Introduction. In Karl Marx: Selected Writings, edited by David McLennen,71-82. New York: Oxford University Press.

Marzak, D. 2016. Theopolitics: Theology and Politics Needed to Understand World News Today. New Era (December 10). https://newera.news/whatis-theopolitics-and-why-is-it-needed// (Accessed 6 June 2018).

Mostafanezhad, M. 2013. 'Getting in Touch with Your Inner Angelina': Celebrity Humanitarianism and the Cultural Politics of Gendered Generosity in Volunteer Tourism. Third World Quarterly 34(3): 485-499.

Nussbaum, M. 1996. Compassion: The Basic Social Emotion. Social Philosophy and Policy 13(01): 27-58.

Reitsma, J., P. Scheepers, and M. Grotenhuis. 2006. Dimensions of Individual Religiosity and Charity: Cross-National Effect Differences in European Countries?. Review of Religious Research 47(4): 347-362.

Saroglou, V., I. Pichon, L. Trompette, M. Verschueren \& R. Dernelle. 2005. Prosocial Behavior and Religion: New Evidence Based on Projective 
Measures and Peer Ratings. Journal for the Scientific Study of Religion 44(3): 323-348.

Schnable, A. 2015. Religion and Giving for International Aid: Evidence from a Survey of U.S. Church Members. Sociology of Religion 76(1):72-94. https://doi.org/10.1093/socrel/sru037.

Sohn, M. 2014. The Good of Recognition: Phenomenology, Ethics, and Religion in the Thought of Levinas and Ricoeur. Houston: Baylor University Press.

Taylor, C. 1997. The Politics of Recognition. In New Contexts of Canadian Criticism, edited by A. Heble, D. P. Pennee, and J.R. Struthers, 98-131. Peterborough, ON: Broadview Press.

Ticktin, M. 2014. Transnational Humanitarianism. Annual Review of Anthropology 43:273-289.

Tilly, C., and S. Tarrow 2007. Contentious Politics. Boulder: Paradigm Publishers.

Turcotte, Martin. 2012. Charitable Giving by Canadians. Canadian Social Trends 11: 18-36. http:/oacao.ca/uploads/3/2/9/4/3294559/charitable giving_by_canadians.pdf.

Young, I. M. 2006. Responsibility and Global Justice: A Social Connection Model. Social Philosophy and Policy 23(01): 102-130.

Amy Kaler is Professor of Sociology at the University of Alberta. Her research focuses on sexual and reproductive health in sub-Saharan Africa, with particular attention to the cultural, social and institutional dimensions of public health interventions. She also works on the dynamics of broad economic transformation and rural household survival in Africa, and in the evolving functions of international development and humanitarian assistance.

Email: amy.kaler@ualberta.ca

John Parkins is Professor of Environmental Sociology at the University of Alberta. His areas of research are focused around energy and society, gender and food security, sustainable agriculture, public engagement, social impact assessment and natural resource management.

Email: jparkins@ualberta.ca

Robin Willey is Professor of Social Sciences at Concordia, University of Edmonton. His research has generally focused on Evangelical Christianity in Canada. He has previously published articles on the difficulties of conducting research in church communities and the sexual practices of Evangelical young adults. His current research looks to investigate the changing theopolitical orientations of Canadian Evangelicals

Email: robin.willey@,concordia.ab.ca 